\title{
Field Base Teaching: A Malaysian Experience
}

\author{
Raman Mariyappan \\ College of Law, International Studies and Government, Doctorate Candidate \\ raman@uum.edu.my
}

\section{Doi:10.5901/jesr.2015.v5n1s1p121}

\begin{abstract}
This paper narrates the field base teaching method that has been incorporated in Northern University of Malaysia. By tradition, the university is a management university, which emphasis on management skills, such as banking, finance, entrepreneurship and other essential components of management. Beginning of 1995, the university realizes that a wider curriculum scope is needed to cater ever growing demand on humanities programs. As a result of this, courses such as history, sociology, anthropology, geography and other courses related to humanities programs were introduced. Components of geography were introduced as regional geography and environmental management in 1997 as one of the elective subject in Public Administration Undergraduate Program. Generally, the teaching method being employed at the university was lectures, tutorial and the assessments were more exams oriented. Starting from the academic session of 2000/2001, the evaluation processes were altered and assignments were introduced. I took this opportunity to introduce assignments based on report writing about development projects and its impacts on natural environment surroundings the university. This paved way for the students to conduct surveys and data collection prior to the report writing. Slowly, I introduced the idea and the importance of field base teaching to the students and the management. Initially it was well perceived by the management and the students. Latter, when the number of students increased from merely 20 to few hundreds, issues such logistics, cost and other related issues influenced the management to rethink the idea of field base teaching. At present the number of students varies from 1,000 to 1,500 per academic semester. The numbers of instructors were also increased from one to fifteen. Unfortunately my present role as an instructor and coordinator does not provide the luxury of practicing field-based teaching due to financial and man power constrain. It is an uphill task to design a syllabus and convince the faculty members to participate in the field based teaching.
\end{abstract}

Keywords: field base teaching, teaching, method, university

\section{Introduction}

Education plays a fundamental role in creating a well-structured society. Education promotes self-identification, creates self-ability in order to participate and function in a society. Discovering self is very important because this lead to harmony in a society. Each individual are unique in the sense that he/she displays a different pattern of thinking and displays various ways of doing things. This is called process of education. It is very crucial that each individual must attain self- knowledge or self-excellence (Romeo Aquino, 2010). So education is an essential tool that our modern society needs to progress in various fields.

Education plays vital role in transforming society and improving community's living standard. Education also plays an important role in enhancing economic growth and economic development. So, the government has the responsibility to run the education system for the benefits of the public. In this context the tertiary education system also comes under the state's social responsibility. Meanwhile the stakeholders involved are government, public, parents, students and many others. It is an essential for the stockholder's active participation to ensure the maximum benefits from the public education system. In Malaysia, several public universities were formed to cater the ever increasing demand for tertiary education. Universiti Utara Malaysia or Northern University of Malaysia was one of the public universities funded fully by the Federal Government to fulfill the government's agenda in education transformation.

Northern University of Malaysia or Universiti Utara Malaysia was formally incorporated on $16^{\text {th }}$ February 1984, with the unique mission to provide academic excellence in the areas of business management, education, information technology, and quality management. Faced with this challenging task, the university has since its inception, ensured that its academic niche areas are focused on such disciplines as management, accountancy, economics, information technology, entrepreneurial development, tourism management, banking \& finance, social development, human resource development and international affairs management. Active learning occurs when students are mentally engaged in 
processing knowledge in order to construct understanding. Through mental engagement, meaning is made, learning is internalized, and knowledge, skills, and concepts are applied (Starnes \& Carone, 2002).

In many classroom settings today, however, it is not uncommon to observe students taking a fairly passive role in their learning. This is especially the case when instructors employ mainly traditional methods of teaching (i.e., lecturing, note-taking, and using multiple-choice and true-false exams). Unfortunately, while these methods can be convenient for the instructor, they often do not impact student learning in a significant way. As reported by Wingfield and Black (2005), passive methods of teaching are likely to be more instructor-centered. Conversely, active styles of teaching foster greater student participation, which oftentimes results in more intense and longer-lasting learning. Active learning has also been linked to critical thinking, increased levels of social integration resulting in subsequent institutional commitment, and enhancement of the well-being and personal growth of students (Braxon, Milem, \& Sullivan, 2000; Koljatic \& Kuh, 2001). Field-based instruction, a form of active learning, has proven to be worthwhile to enhancing student learning outcomes, including retention of the subject matter, and improving student's problem solving skills (Davis, 1993). Field experiences are learner-centered, allowing students the opportunity to apply ideas and concepts taught in a traditional classroom setting to an environment that stimulates critical thinking and analysis (Hickcox, 2002). Field experiences enable students to further develop cognitively from more simplistic positions (Barr \& Tagg, 1995; Ediger, 2001).

As a geographer I was trained and exposed well in field based teaching. Unfortunately my present role as an instructor and coordinator does not provide the luxury of practicing field-based teaching due to financial and man power constrain. It is an uphill task to design a syllabus and convince the faculty members to participate in the field based teaching.

\section{The Puzzle}

Geography was first introduced as regional geography in 1997/98 academic session at Northern University of Malaysia. The author was given the responsibility to outline the curriculum syllabus. Based on the university's practice at the time, the teaching mode were lectures and assessment based on exams. Furthermore the subject was only an elective subject, part of the Public Management Program. The first batch consists of 16 students and none of the students had previous learning experience on geography or geography related issues. This was really challenging for the author to design the lecture notes in order to cater the student's needs. The issue was whether to introduce a different set of leaning objectives and learning outcomes. The teaching method also designed differently with introduction of field work observation and data collection. Since the students did not have any knowledge on field observation techniques, they were given simple assignment such as fauna and flora observation (natural geography) and traffic analysis (human geography). Unfortunately the students cannot perform this simple task due to lack of knowledge. The first puzzle was that, what is the best teaching method to employ to this group of students?

For the past 5-10 years the author was involved in teaching courses such as Environmental Management and Social Science Studies. As a coordinator for the Social Science Studies, part of my responsibilities is to design the syllabus. The Social Science Studies comprises of various disciplines and one of which is Geography and Environmental Management. Each semester the number of students ranges from one thousand to two thousand five hundred from various faculties (Law, Accounting, Finance, Business Management, Computer Studies, International Studies, Public Management, Developmental Management, Project Management, Housing Management, Communications, Communication Business, International Business and many other courses. Devising a workable field-based program was contentious because the change entailed much than combining faculty and curriculum.

Due to the large number of students, basically the approach is 32 hours of theoretical teaching and 10 hours of field-based teaching. The students will be divided into smaller groups (10-15) and given first-hand experience (one day trip) on the issues such as policy formulation and policy implementation by various government agencies. The students will be placed (for one day) in government agencies and private sectors which is related to environmental management, such as irrigation agency, land agency, department of environment, river agency, department of agricultural, local authorities, housing developers and public utility departments. Then students will come out with a mini report (15 pages) and a presentation (10 minutes) based on the field trip. The report and presentation must entirely base on their experience gained from the various agencies.

The author realized that there are several shortcomings: i) one day field trip is not sufficient, ii) participating government agencies are below par, iii) the accompanying officer from the government agencies are not equipped with proper knowledge or information and iv) the total number of students and too many groups are too large for a field-based teaching. Due to various constrains the field-base component being revised and probably will be phased out sooner. This 
is due the instructors were not keen and the monetary resources cannot sustain the field-based teaching expenses.

\section{Discussion}

Fortunately the field-based teaching of Environmental Management is more pragmatic and futile towards end results. During the past three years I am involved designing the suitable field-based teaching syllabus that benefited most to the students and the instructors. This course is about managing the environmental resources such as water, forest, land, coast, wetlands, rivers and etc. The course involves three phases starting from the third semester until the sixth semester. The third semester comprises of 32 hours of theoretical teaching and 10 hours of field-based teaching. The theoretical teaching is about four earth spheres and various ecosystems and the relation to human activities. The field trip involves visit to Forest department, Irrigation department, Department of environment, Department of minerals and other government agencies that deals directly about environmental resources. Based on the theoretical findings and the relations to the field trip will be presented in the class room comprising 15-20 minutes presentation.

The fourth semester is 20 hours of theoretical teaching and 22 hours of field-based teaching. The field-trip involves visiting and experiencing the management of reservoir, wetlands, rivers, forest reserves, forest parks, beaches and etc. This is really exciting because the students will get to see natural process at work, the importance of hydrological cycle, the importance of trees, coastal processes etc. The students will prepare a report how man interacts with nature.

The fifth and sixth semester is about 30 hours of field-based teaching. The students will collaborate with local communities such schools, business communities, farmers, professionals, non governmental agencies to design a project that reflects man's responsibilities' towards environmental resources. This involves projects such as: a) adopting a stream, b) conserving water, c) clean water streams and fish, d) water pollution, e) earth day, f) ecosystems, g) importance of mangroves, h) plant a tree, i) pollution, j) recycle. At the end of the sixth semester a comprehensive report will be prepared. The most outstanding report will be given priority to be developed into a graduation thesis. Refer to table 1.

After 3-4 years of experimenting, I realize that field based teachings with sound theoretical background; the whole teaching and learning process were much more educational and practical. It also gives a new dimension to the teaching profession at the tertiary level. Let me share my experience with a good case study involving the replanting of mangroves in Penang Island. During the Third Semester the students were taught about mangroves and its importance to the coastal system especially in Malaysia. A visit to the one of the best managed mangrove forest in Malaysia that is Matang Mangrove Forest ${ }^{1}$ in Perak, Malaysia, enhance the participants/student knowledge to understand better the mangrove ecological system.

To practice what had been learned in the classroom and at Matang mangrove Forest, we decided to volunteer for two programs called "Save the Mangrove Forest in Penang"2 and "Clean the Gurney Drive Coastal Waters"3 organized by the Penang State Government in 2009 and 2010.

The students were divided into two groups and the first groups were involved in the mangrove replanting and the other groups were involved in the cleaning of Gurney Drive. Some 1,000 saplings were planted off the Marina Bay

\footnotetext{
${ }^{1}$ Matang Mangrove Forest Reserve in the largest single forest in Peninsular Malaysia, covering an area of 40,151ha. It is one of the world's best well-managed mangrove swamps. The forest reserve has received various international awards. Mangrove eco-systems are highly productive and represent the life support systems for fisheries, forestry, medicine, food and other products. Within this mangrove swamp are found multitudes of tree species, birds and marine life which is haven to natural lovers (Perak Tourism Board, 2014).

2 The eastern coastal of Penang Island is undergoing tremendous changes in the past 30 years. Observation would tell us that once the east coast of Penang Island was full of mangroves forest with various species of flora and fauna. The swamps were reclaimed to cater for the ever growing industrial, commercial and housing sectors.

${ }^{3}$ Gurney Drive is a popular seafront promenade in Georgetown, Penang, Malaysia. The road also one of Penang's most popular tourist destinations, famous for the hawker food. Previously known as the New Coastal Road, which was completed in 1936 and renamed in 1952 after Sir Henry Gurney, the British High Commissioner of Malaya (1950-1951). Over the years, the beaches along Gurney Drive have largely been lost to coastal erosion. More recently, a land reclamation project near by area Tanjung Tokong has reversed the erosion, leading to accretion of silt and mud off Gurney Drive. Mangrove sapling has sprouted in the mud, which is now frequented by egrets and other birds, as well as mudskippers. There have suggestions that the Gurney Drive coastal area, formerly earmarked for reclamation under the Penang Outer Ring Road project (at present suspended), be reclaimed for a recreational park or allowed to develop into mangrove forest.
} 
condominiums near Tanjung Tokong. The other group was involved in making EM mud balls ${ }^{4}$ and throwing into the Gurney Drive coastal waters. Both the activities were instrumental for the undergraduates about understanding the process of nature that they decided to continue to participate on their own during weekends. This is just one of the examples that I experimented and bravely can say that the field-based teaching has great potential to offer compare to the class room based method. Nevertheless the number of participant is very essential in-order to achieve the outlined objectives of the syllabus.

Table 1. Summary of the field-base teaching that relates to activities, evaluation and cost.

\begin{tabular}{|c|c|c|c|c|l|l|l|}
\hline Item & Sem & No. of students & \multicolumn{2}{|c|}{ Teaching (hrs) } & Activities & Evaluation & \multicolumn{1}{c|}{ Cost } \\
\hline 1 & 3 & 60 & 32 & 10 & $\begin{array}{l}\text { Educational Visits; Forrest } \\
\text { department, Irrigation } \\
\text { department, DOE, etc }\end{array}$ & $\begin{array}{l}\text { Group presentation; policy } \\
\text { formation \& policy implementation }\end{array}$ & $\begin{array}{l}\text { 10-15 usd per } \\
\text { student }\end{array}$ \\
\hline 2 & 4 & 60 & 20 & 22 & $\begin{array}{l}\text { Educational visits; Reservoir, } \\
\text { Wetland, river, Forrest reserve, } \\
\text { Beach parks }\end{array}$ & $\begin{array}{l}\text { Report writing; how man interacts } \\
\text { with nature }\end{array}$ & $\begin{array}{l}20 \text { usd per } \\
\text { student }\end{array}$ \\
\hline 3 & $5 \& 6$ & 60 & 12 & 30 & $\begin{array}{l}\text { Design a project which reflects men's responsibilities towards } \\
\text { mother nature; planting trees, recycling, adopting stream }\end{array}$ & $\begin{array}{l}10-15 \text { usd per } \\
\text { student }\end{array}$ \\
\hline
\end{tabular}

Source: Raman, 2010.

\section{Advantages}

Mary Jane Gray (1975) argues that field base teaching must be incorporated in elementary school. She outlines three major areas; cooperating teachers, cooperating schools and evaluating effectiveness of students prepaid in this way. She emphasizes on availability and usage of a laboratory, which plays essential role in this education system. In the long run the system brings the result which is far better than class room base teachings.

Maryellen Weimer 2009, on the other hand carefully scrutinizes the following which supports the PBL. From the student's perspectives, PBL creates student centered approach, which can be used as yardstick to outline the ability of the student's achievements. PBL also creates an enjoyable and satisfying scenario. This can be explained by sighting an example where any kind of interaction with public or specific person will create anxiety and develop interest from the students to participate actively. A personal experience encourages greater understandings with gathered information. This garners higher abilities and develops lifelong learning skills. From the instructor's perspectives, PBL enhances the class attendance increases due to intense class room discussion among students. This method affords more intrinsic reward and encourages students spend more time studying. PBL also promotes interdiciplinarity interaction, which benefits the students. From the institutions perspectives, PBL makes student learning a priority and helps students' retention. PBL also may be taken as evidence that an institution values teachings.

The PBL promotes a dynamic learning approach. It also creates a suitable atmosphere for group discussions, synthesizing ideas, promotes lifelong learning experiences, new studying approaches cultivates student centered learning process, betterment the sharing process, instills sense of belonging among students, creates networking with outside world, connects people from various disciplines and promotes active participation.

\section{Disadvantages}

Maryellen Weimer 2009, from the students' perspectives, prior learning experiences do not prepare well for PBL. It also takes more time and takes away study time from other subjects. PBL creates anxiety because learning is no more in systematic manner. Due to group dynamics issues compromise PBL defectiveness and maybe less content knowledge may be learned. From the instructors perspectives, to create suitable problem scenario is difficult. This again warrants more preparation time for the lessons. It is very difficult to pinpoint the exact needs of each student. Sometimes group dynamic issues may require faculty intervention. Lastly the assessment being employed may be in question mark.

${ }^{4}$ EM mud balls are a bio-remedial environmental solution of reducing water pollutants and improving water quality of rivers. The fermentation emitted from the mud balls will prevent algae growth and pathogenic microbes which causes infectious diseases 
Other than that, one of the most disadvantages using the field base teaching method is the high costing involved. The table 1.1 shows, every aspect of the field base teachings involves expenses. Initially the expenses were low, but as the number of students gets bigger as per semester, the expense also soars up. The faculty does not want to burden the students with the extra expenses and at the same time the faculty also does not want to own the responsibility of sharing the expenses. From the institutions perspectives, PBL requires a change educational philosophy for faculty who mostly lecture. To support the additional burden, the faculty will need to incorporate faculty staff development and support for PBL. Again it involves more recruitment of instructors. It also needs a better classroom, if possible a laboratory with flexible classroom space. Definitely it will engender resistance from faculty who questions its efficacy.

\section{Conclusion}

This paper is about sharing the experience on the field-base teaching method. Field-base teaching offers variety in the context learning. It also enhances and enriches the learner's ability to analyze a particular issue from different perspective. The instructor also gains valuable experience through trial and error. Teaching and learning becomes very much interesting and the whole process of learning is given a new dimension.

\section{References}

Pawson, E., Fournier, E., Haight, M., Muniz, O., Trafford, J., and Vajoczki, S. 2006. Problem-based learning in geography: Towards a critical assessment of its purposes, benefits and risks. Journal of Geography in Higher Education 30 (1): 103-16.

Aquino, R. (2010, July 25). The Role of Education towards Individuals and Society. Retrieved February 27, 2015, from http://ezinearticles.com/?The--Role--of--Education--Towards--Individuals--and--Society\&id=4735373

Starnes, B., Et Carone, A. (2002). From thinking to doing: The Foxfire core prac- tices. Mountain City, GA: Foxfire Fund. Tassoni, J., Et Leweicki-Wilson, C. (2002)

Stewart-Wingfield, S., \& Black, G. S. 2005. Active versus passive course designs: The impact on student outcomes. Journal Small Business Institute $®$ National Proceedings Vol. 33, No. 1 Winter, 2009 of Education for Business, 81(2), 119-125.

Braxton, J. M., Milem, J. F., and Sullivan, A. S.(2000). "The Influence of Active Learning on the

College Student Departure Process: Toward a Revision of Tinto's Theory." Journal of

Higher Education, 2000, 71(5), 569-590.

Koljatic, M. \& Kuh, G. D. (2001). A longitudinal assessment of college student engagement in good practices in undergraduate education. Higher Education, 42, 351-371.

Davis, B. G. (1993). Tools for Teaching. Jossey-Bass Inc., San Francisco: California.Hickcox, 2002).

Barr, R. B., \& Tagg, J. (1995). From teaching to learning: A new paradigm for undergraduate education. Change Magazine, $27(6), 12-$ 25.

Ediger, M. (2001). Assessment, Geography, and the Student. Journal of Instructional Psychology ,28 (3).

Maryellen Weimer 2009. Developing learner-centered teaching: a practical guide for faculty. Jossey-Bass, 2009 
ISSN 2239-978X

ISSN 2240-0524
Journal of Educational and Social Research MCSER Publishing, Rome-Italy
Vol. 5 No.1 S1 April 2015 